\title{
The In Vitro and In Vivo Effects of Human Growth Hormone Administration on Tumor Growth of Rats Bearing a Transplantable Rat Pituitary Tumor (7315b)
}

\author{
ARJEN BINNERTS,* PIET UITTERLINDEN, LEO J. HOFLAND, PETER v. KOETSVELD and STEVEN W.J. \\ LAMBERTS
}

Department of Medicine and Clinical Endocrinology, Erasmus University, Dr Molewaterplein 40, 3015 GD Rotterdam, The Netherlands

\begin{abstract}
The direct effects of human GH and IGF-I on PRL secretion and cell proliferation were studied on PRL secreting rat pituitary tumor $7315 b$ cells in vitro, as well as the effects in vivo of human GH administration on body weight, IGF-I levels and tumor size in rats bearing this transplantable tumor. In the in vitro studies IGF-I levels above $5 \mathrm{nM}$ stimulated PRL release in a dose-dependent manner while $G H$, in concentrations of $0.23-45 \mathrm{nM}$, did not affect PRL release. Cell proliferation was stimulated by $I G F-I$ in a dose-dependent manner from $0.5 \mathrm{nM}$ onwards, while $\mathrm{GH}$ did not have an effect. The in vivo studies showed that $1 \mathrm{mg} \mathrm{GH} / \mathrm{rat} /$ day prevented tumor-induced cachexia and normalized the suppressed IGF-I levels without stimulating tumor growth. It is concluded that tumor-induced cachexia can be prevented by exogenous $G H$ administration without an increase in tumor mass, even if a tumor model is used whose cultured tumor cells respond to exposure to IGF-I with a mitotic response.
\end{abstract}

\section{INTRODUCTION}

In ANIMALS, as well as in man, growth hormone (GH) exerts a wide variety of effects. Most of its growth-promoting actions are mediated via the formation of insulin-like growth factor I (IGF-I) while it also exerts a direct lipolytic action [1]. Knowledge about the effects and possible therapeutic uses of $\mathrm{GH}$ in adults has been limited by the lack of available supplies. Therefore during the past decades its use has mainly been restricted to the treatment of children with short stature.

After human GH, which is identical and bioequivalent to endogenous $\mathrm{GH}$, was produced by recombinant DNA technology, new reports concerning the usefulness of GH therapy in adults with various catabolic disorders (trauma, surgery) were published [2-5]. To date no studies have been carried out on the potential beneficial anabolic effects of GH therapy in cancer patients.

Cancer-induced cachexia diminishes the quality of life significantly and may be attenuated by GH

\footnotetext{
Accepted 26 October 1989.

*'To whom all correspondence and reprint requests should be addressed.
}

therapy. The amount of weight loss in cancer patients is positively correlated with the overall mortality. In addition, improvement of nutritional status may reduce chemotherapy related toxicity, as has recently been shown in a rat model [6]. The usefulness of (par)enteral (hyper)alimentation in the management of cancer patients is controversial [7-10].

Controversy exists also concerning the possible carcinogenic and/or tumor growth-stimulating effects of $\mathrm{GH}$ treatment in humans with $\mathrm{GH}$ deficiency, either direct or mediated by circulating or locally produced IGF-I [11-13]. According to some investigators the incidence of neoplasms in acromegaly is increased [14-17], though others did not observe this relation $[18,19]$.

In the present study we investigated the direct effects of human GH and IGF-I on prolactin (PRL)secreting rat pituitary tumor $7315 \mathrm{~b}$ cells in vitro, as well as the effects of human GH administration to rats bearing the transplantable rat pituitary tumor $7315 \mathrm{~b}$. In the in vitro experiments the effects on cellular DNA content and PRL secretion were investigated, while in the in vivo experiments changes in tumor size, body weight, plasma IGF-I, PRL and $\mathrm{GH}$ levels were studied. 


\section{MATERIALS AND METHODS}

\section{In vitro tumor cell experiments}

Female Buffalo rats (R.B.I., Rijswijk, the Netherlands), weighing 150-170 g, were kept in an artificially illuminated room $(08.30-20.30 \mathrm{~h})$ with food and water ad libitum. The animals were inoculated subcutaneously between the scapulae with a cell suspension of the transplantable, PRL-secreting $7315 \mathrm{~b}$ rat pituitary tumor as described in detail elsewhere [20]. Three to four weeks aftcr inoculation of the tumor cell suspension a tumor of approximately $20 \mathrm{~cm}^{2}$ has grown on the back of the animals. At this moment the animals were killed by an overdose of ether anesthesia and the tumor was carefully removed and collected in a sterile saline solution $(9 \mathrm{~g} / \mathrm{l} \mathrm{NaCl})$.

$7315 \mathrm{~b}$ pituitary tumor cells were isolated by mechanical dispersion. The isolated tumor was washed twice with calcium-, magnesium-free Hank's balanced salt solution (HBBS) supplemented with $1 \%$ human serum albumin (HSA), penicillin $\left(10^{5} \mathrm{U} / \mathrm{l}\right)$, streptomycin $(100 \mu \mathrm{g} / \mathrm{l})$, fungizone $(0.5 \mathrm{mg} / \mathrm{l})$ and sodium bicarbonate $(0.4 \mathrm{~g} / \mathrm{l}$ final concentration). The capsula of the tumor was carefully removed, after which the tumor was minced into small pieces. The remaining suspension of tumor tissue was gently vortexed for $30 \mathrm{~s}$. After vortexing the suspension was centrifuged at $600 \boldsymbol{g}$ for $5 \mathrm{~min}$ and the pellet was washed twice with HBSS + HSA. The remaining pellet was resuspended in HBSS + HSA and the suspension was filtered over a nylon gauze. In order to separate vital from non-vital cells the suspension was layered on Ficoll-Isopaque (density $1.077 \mathrm{~g} / \mathrm{ml}$; prepared by the Dijkzigt Hospital Pharmacy, Rotterdam, the Netherlands) and centrifuged at $500 \mathrm{~g}$ for $20 \mathrm{~min}$. The interphase containing vital cells was collected and washed twice with HBSS + HSS. Finally, the cells were resuspended in culture medium.

The culture medium used in all experiments consisted of minimal essential medium with Earle's salts (MEM) supplemented with MEM non-essential amino acids, sodium pyruvate $(1 \mathrm{mmol} / \mathrm{l}), 10 \%$ fetal calf serum, penicillin $\left(10^{5} \mathrm{U} / \mathrm{l}\right)$, streptomycin $(100 \mu \mathrm{g} / \mathrm{l})$, fungizone $(0.5 \mathrm{mg} / \mathrm{l})$, L-glutamine $(2 \mathrm{mmol} / \mathrm{l})$ and sodium bicarbonate $(2.2 \mathrm{~g} / \mathrm{l}$ final concentration). The medium was adjusted to $\mathrm{pH}$ 7.4 with $1 \mathrm{~mol} / 1 \mathrm{NaOH}$. The $7315 \mathrm{~b}$ pituitary tumor cells were seeded at a density of 20,000 cells per well in $1 \mathrm{ml}$ of culture medium in 24-well plates (Costar, Cambridge, Mass, U.S.A.) without or with IGF-I or GH. The number of replicate points is 4 . After 6 days of culture the media and cells were collected and stored at $-20^{\circ} \mathrm{C}$ until analysis. Medium and supplements were purchased from Grand Island Biological Co. Europe (Paisley, U.K.). IGF-I was obtained from Bachem (Bachem
Feinchemicalien ASG, Bubendorf, Switzerland) and human recombinant growth hormone $(\mathrm{GH}$, Humatrope) from Eli Lilly \& Co, Indianapolis.

Rat PRL concentrations in the culture media were measured by a double antibody RIA using materials and protocols supplied by the distribution officer of the NIADDK. All results are expressed in rat prolactin reference preparation-1 (RP-1).

The DNA content of the tumor cells was determined as described in detail elsewhere [21]. The method is based on a DNA-dependent fluorescence enhancement of a fluorochrome. In short, cultured tumor cells, which did not attach to the floor of the wells, were collected at the end of the incubation period and washed twice with an ice-cold saline solution. The remaining cell pellet was stored at $-20^{\circ} \mathrm{C}$ until analysis. The cells were extracted with $300 \mu \mathrm{l}$ ammonia solution $(1 \mathrm{~mol} / \mathrm{l})+$ Triton X100 $(0.2 \% \mathrm{v} / \mathrm{v})$ by sonification during $5 \mathrm{~s}$ at amplitude 15 (Soniprep 150; MSE). Thereafter $2 \mathrm{ml}$ assay buffer $(100 \mathrm{mmol} / 1 \mathrm{NaCl}, 10 \mathrm{mmol} / 1 \mathrm{EDTA}, 10$ $\mathrm{mmol} / \mathrm{l}$ Tris; $\mathrm{pH} 7.0$ ) was added. The remaining solution was centrifuged at $2000 \mathrm{~g}$ during $5 \mathrm{~min}$ and $100 \mu \mathrm{l}$ aliquots of the supernatant were mixed with $1.5 \mathrm{ml}$ Hoechst dye $\mathrm{H} 33258$ (100 ng/ml). Fluorcscence was mcasured after 15 min with the exication and emission wavelengths set at $350 \mathrm{nmol} /$ land $455 \mathrm{nmol} / \mathrm{l}$ respectively. Fluorescence of experimental samples was referenced to a standard curve of calf thymus DNA (type II, no D-3636; Sigma Chemical Company, St Louis, Mo, U.S.A.).

Each experiment was done three times, the results shown relate to a single experiment. All data are expressed as mean \pm S.E.

\section{In vivo tumor experiments}

In two experiments the effect of $\mathrm{GH}$ administration on the growth of the $7315 \mathrm{~b}$ tumor and on reversal (experiment 1) or prevention (experiment 2) of tumor-induced cachexia was evaluated. Tumor growth was evaluated by expressing tumor size in centimeters squared (maximum length $\times$ maximum width) which has been shown to be closely correlated with tumor weight [22]. In the first experiment the effects of administration of $1 \mathrm{mg} \mathrm{GH} / \mathrm{rat} /$ day (Humatrope, Eli Lilly \& Co, Indianapolis) subcutaneously in $0.25 \mathrm{ml}$ diluent starting on day 13 after tumor implantation until the end of the experiment (day 23) were evaluated, while in the second experiment the effects of $\mathrm{GH}$ administration for 15 days starting on the day of inoculation were evaluated. In both experiments tumor-bearing controls received daily injections of diluent only while in the second experiment the effects of either GH or diluent was evaluated in non-tumor-bearing controls as well. Each group of animals consisted of six rats.

Plasma IGF-I levels were measured in EDTA plasma obtained from the tail vein during the exper- 
iment or after decapitation at the end of the experiment. The commercial kit for the determination of IGF-I from the Nichol's Institute of Diagnostics (San Juan Capistrano, CA, U.S.A.) was used. The intra-assay cv was 7.2 and the inter-assay cv $12.8 \%$. PRL was determined in the same samples by double antibody RIA as described above.

\section{Statistical evaluation}

Statistical analysis was done by analysis of variance, followed by Duncan's test for determining the differences between control and experimental groups. In the in vivo experiments changes in body weight were evaluated by Student's unpaired $t$ test.

\section{RESULTS}

The effects of IGF-I and GH on PRL secretion and DNA content of cultured $7315 \mathrm{~b}$ tumor cells

The $7315 \mathrm{~b}$ tumor cells were cultured for a period of 6 days. The effects of a wide concentration range of IGF-I $(0.5-50 \mathrm{nmol} / \mathrm{l})$ and GH $(0.23-45 \mathrm{nmol} / \mathrm{l})$ were investigated (Fig. 1). Low concentrations of 0.5 and $1 \mathrm{nmol} / \mathrm{I}$ IGF-I did not affect PRL release, while 5, 10 and $50 \mathrm{nmol} / \mathrm{l}$ IGF-I stimulated PRL rclease in a dose-dependent manner $(5 \mathrm{nmol} / \mathrm{l} \mathrm{vs}$. control: $P<0.01 ; 10$ vs. $5 \mathrm{nmol} / \mathrm{l}: P<0.05 ; 50$ vs. $10 \mathrm{nmol} / \mathrm{l}: P<0.05)$. A low concentration of IGF-I $(0.5 \mathrm{nmol} / 1)$ stimulated the DNA content of the cells after 6 days by $12 \%$ ( $P<0.05$ vs. control), while higher concentrations of IGF-I stimulated the
DNA content in a dose-dependent manner, 10 $\mathrm{nmol} / \mathrm{l}$ being the maximal stimulatory concentration (stimulation by $1,5,10$ and $50 \mathrm{nmol} / \mathrm{l}$ IGF-I being $24,37,50$ and $55 \%$ respectively, 1 and 5 vs. $0.5 \mathrm{nmol} / \mathrm{l}: P<0.05 ; 10$ and 50 vs. $1 \mathrm{nmol} / 1$ : $P<0.01)$. We also measured the IGF-I concentration of the culture medium used in these experiments: the final IGF-I concentration of the medium to which the control cells were exposed amounted to $0.2 \mathrm{nmol} / \mathrm{l}$.

Human GH in a concentration between 0.23 and $45 \mathrm{nmol} / 1$ did not affect PRL release, while it did also not influence the DNA content of the tumor cells after 6 days of culture (Fig. 1).

The effect of the administration of human $G H$ in vivo on $7315 b$ tumor growth, body and organ weights, serum PRL. and IGF-I levels in rats

The daily, subcutaneous administration of a pharmacological dose of $1 \mathrm{mg} \mathrm{GH} /$ rat per day for 10-15 days was investigated on $7315 \mathrm{~b}$ tumor growth in two separate experiments.

In the first experiment $\mathrm{GH}$ was injected daily from day 13 till 23 after tumor implantation. $\mathrm{GH}$ administration did not affect pituitary tumor growth: tumor size (as expressed in $\mathrm{cm}^{2}$ ) did not differ from that found in tumor-bearing animals which received the diluent only (Fig. 2). In contrast, however, the GH-treated tumor bearing rats had gained weight considerably. In Fig. 2 it is shown that tumor-bearing control animals gained
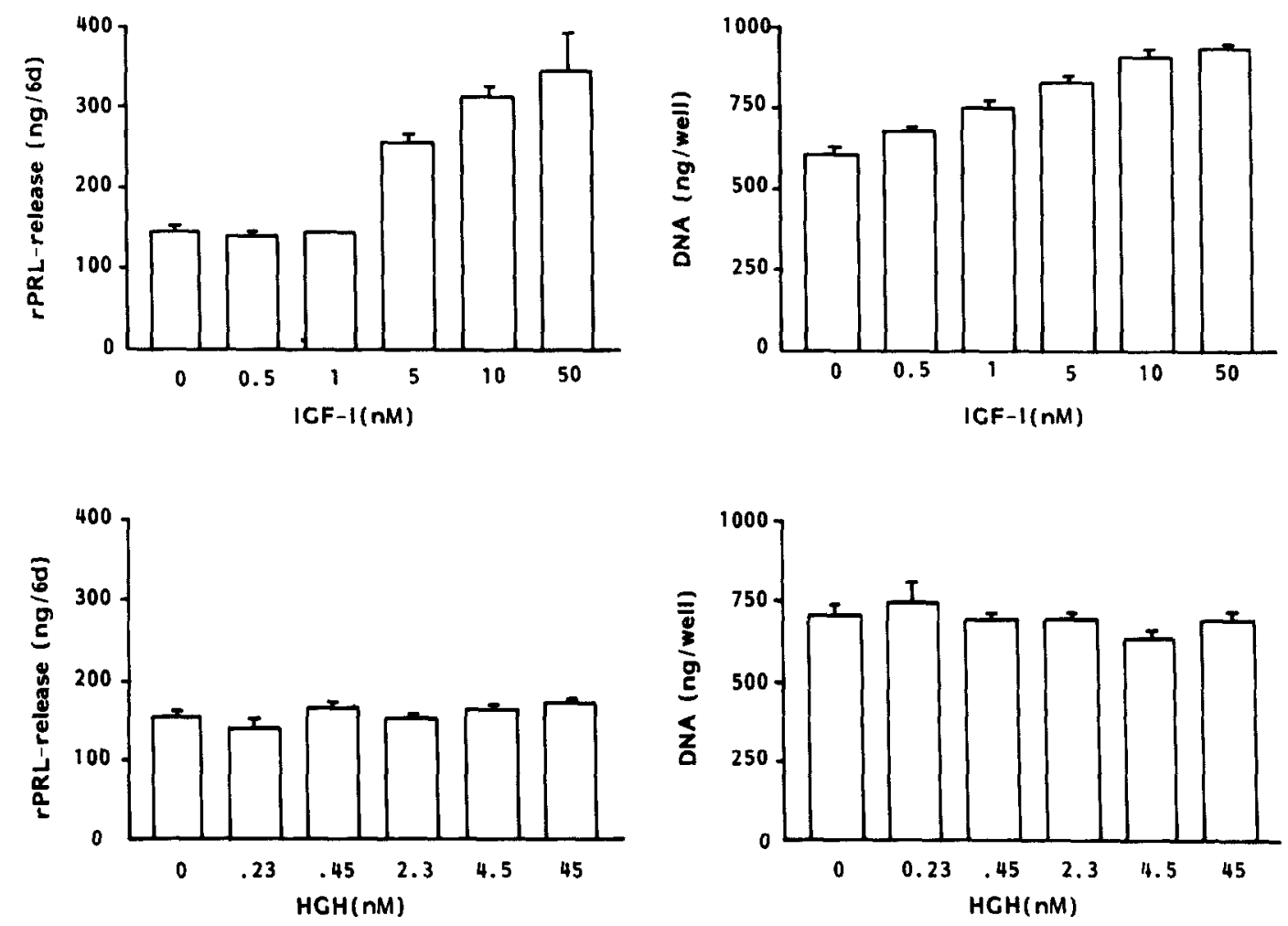

Fig. 1. The effects of increasing concentrations of IGF-I (upper panels) and GH (lower panels) on rat PRL release (ng/6 days) and DNA content ( $\mathrm{ng} /$ well) of $7315 \mathrm{~b}$ tumor cells cultured for 6 days. 

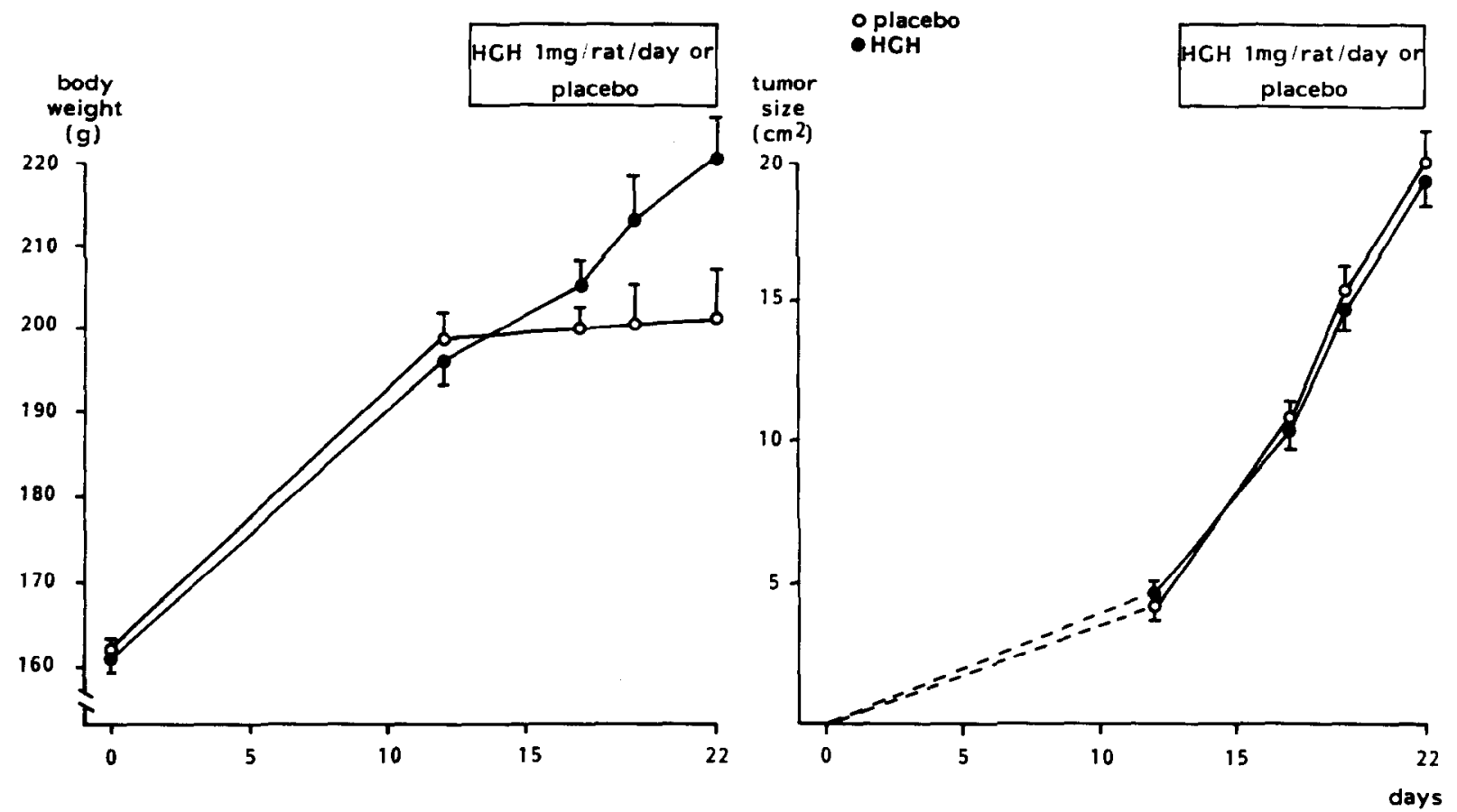

Fig. 2. The effects on body weight, uncorrected for tumor weight (left panel; $\mathrm{g}$ ) and tumor size (right panel; $\mathrm{cm}^{2}$ ) of the administration of human $G H(1 \mathrm{mg} / \mathrm{rat} /$ day $)$ or placebo for 10 days to rats bearing the transplantable rat pituitary tumor $7315 b$ starting on day 13 after tumor implantation. $\mathrm{n}=6$ for each group; mean \pm S.E.M.

$4.5 \pm 6 \mathrm{~g}$ (mean \pm S.E.M.) in weight during the 10 day placebo treatment period, while the $\mathrm{GH}$ treated tumor-bearing rats gained $24.3 \pm 1 \mathrm{~g}$.

After deduction of the mean tumor weight $(35.1 \pm 5 \mathrm{~g}$ in the placebo treated and $40.5 \pm 2 \mathrm{~g}$ in the GH-treated animals; NS) the weight of the placebo-treated animals amounted to $166 \pm 6 \mathrm{~g}$, indicating a mean body weight gain of only $3 \pm 2 \mathrm{~g}$, in comparison with the mean body weight prior to tumor implantation. The actual mean body weight of the $\mathrm{GH}$-treated group at the end of the experiment amounted to $180 \pm 4 \mathrm{~g} \quad(220.5 \pm 5.4$ minus $40.5 \pm 2$ ). Therefore the GH-treated animals had gained $18 \pm 2 \mathrm{~g}$ in weight during the 22 day investigational period. This weight gain did not differ from that observed in non-tumor-bearing controls (starting weight $161 \pm 2.8$, final weight $175.3 \pm 3.7)$ but was higher than that seen in the tumor-bearing control rats $(P<0.01)$. In comparison with non-tumor-bearing controls plasma IGF-I levels were slightly lowered on day 12 after tumor implantation (NS, Table la). This decrease was statistically significant in the tumor-bearing controls 18 and 22 days after tumor implantation $(P<0.05)$, while $\mathrm{GH}$ treatment in tumor-bearing animals resulted in a significant stimulation of IGF-I to levels which were comparable with those observed in non-tumor-bearing controls (both on day 18 and 22: $P<0.05$ vs. tumor-bearing controls).

Prolactin levels in the GH treated tumor-bearing group did not differ significantly from the placebo- treated tumor-bearing animals (1133 \pm 156 vs. $771 \pm 163 \mathrm{ng} / \mathrm{ml}$ ), though both were significantly higher compared with the non-tumor-bearing controls $(81 \pm 32)$.

In the second experiment $\mathrm{GH}$ administration was started on the day of tumor implantation and continued for 15 days. Again no significant effect of $\mathrm{GH}$ administration on tumor growth was observed (Fig. 3). GH exerted powerful stimulatory effects on body growth both in the non-tumor- and in the tumor-bearing animals. The placebo-treated nontumor-bearing rats gained $14 \pm 2 \mathrm{~g}$ in weight, while in the GH-treatcd control group this amounted to $33 \pm 3 \mathrm{~g}(P<0.01)$. The tumor-bearing placebotreated rats gained $34 \pm 4 \mathrm{~g}$ in weight, but after deduction of tumor weight $(26 \pm 4 \mathrm{~g})$ net weight gain was only $8 \pm 2 \mathrm{~g}$. Growth hormone administration to tumor-bearing animals resulted in a total weight gain of $49 \pm 4 \mathrm{~g}$; after deduction of tumor weight $(29 \pm 7)$ : $20 \pm 2 \mathrm{~g} \quad(P<0.01$ vs. tumorbearing placebo-treated rats).

After 15 days of $\mathrm{GH}$ treatment plasma IGF-I levels in the GH treated non-tumor-bearing rats were significantly elevated compared with the placebo-treated non-tumor-bearing animals $(P<0.05$; Table $1 \mathrm{~b}$ ). The consequences of tumor implantation on IGF-I levels again became evident: both on day 16 and 22 they were significantly suppressed in comparison with the placebo-treated non-tumorbearing rats $(P<0.05$ in both instances $)$. Administration of GH to tumor-bearing rats resulted already on day 9 but also on day 16 in a stimulation of 
Table la. The effect of $G H(1 \mathrm{mg} / \mathrm{rat} /$ day $)$ or placebo administration on the total plasma IGF-I concentration $(\mathrm{nmol} / 1)$ of rats with the pituitary tumor $7315 b$, for 10 days starting on day 12 after tumor implantation (mean \pm S.E.M.; $\mathrm{n}=6$ per group)

\begin{tabular}{lccc}
\hline & \multicolumn{3}{c}{ IGF-I (nmol/l) } \\
& Day 12 & 18 & 22 \\
\hline Control non-tumor & $25.3 \pm 1.6$ & $23.6 \pm 1.0$ & $27.2 \pm 2.4$ \\
Control tumor & $23.1 \pm 1.7$ & $17.2 \pm 1.1^{*}$ & $19.7 \pm 0.9^{*}$ \\
Tumor + GH & $23.2 \pm 0.8$ & $27.7 \pm 1.7^{\dagger}$ & $28.5 \pm 0.7^{\dagger}$ \\
\hline
\end{tabular}

${ }^{*} P<0.05$ vs. control non-tumor.

$+P<0.05$ vs. control tumor.

Table $\mathrm{l} b$. The effect of $G H(1 \mathrm{mg} / \mathrm{rat} /$ dav $)$ or placebo administration on the total plasma IGF-I concentration $(\mathrm{nmol} / 1)$ of rats with the pituitary tumor $7315 b$, for 15 days starting on the day of tumor implantation (mean \pm S.E.M.; $\mathrm{n}=6$ per group)

\begin{tabular}{lccc}
\hline & & IGF-I (nmol/l) & \\
& Day 9 & 16 & 22 \\
\hline Non-tumor placebo & $20.6 \pm 1.0$ & $22.2 \pm 0.5$ & $21.4 \pm 1.0$ \\
Non-tumor + GH & $23.9 \pm 1.1$ & $28.1 \pm 0.6^{*}$ & $25.0 \pm 1.0^{*}$ \\
Tumor placebo & $18.3 \pm 0.7$ & $16.9 \pm 0.5^{*}$ & $14.1 \pm 1.1^{*}$ \\
Tumor + GH & $23.8 \pm 1.1 \dagger$ & $25.9 \pm 0.7 \dagger$ & $15.8 \pm 1.1$ \\
\hline
\end{tabular}

${ }^{*} P<0.05$ vs. non-tumor placebo.

$\dagger P<0.05$ vs. tumor placebo.
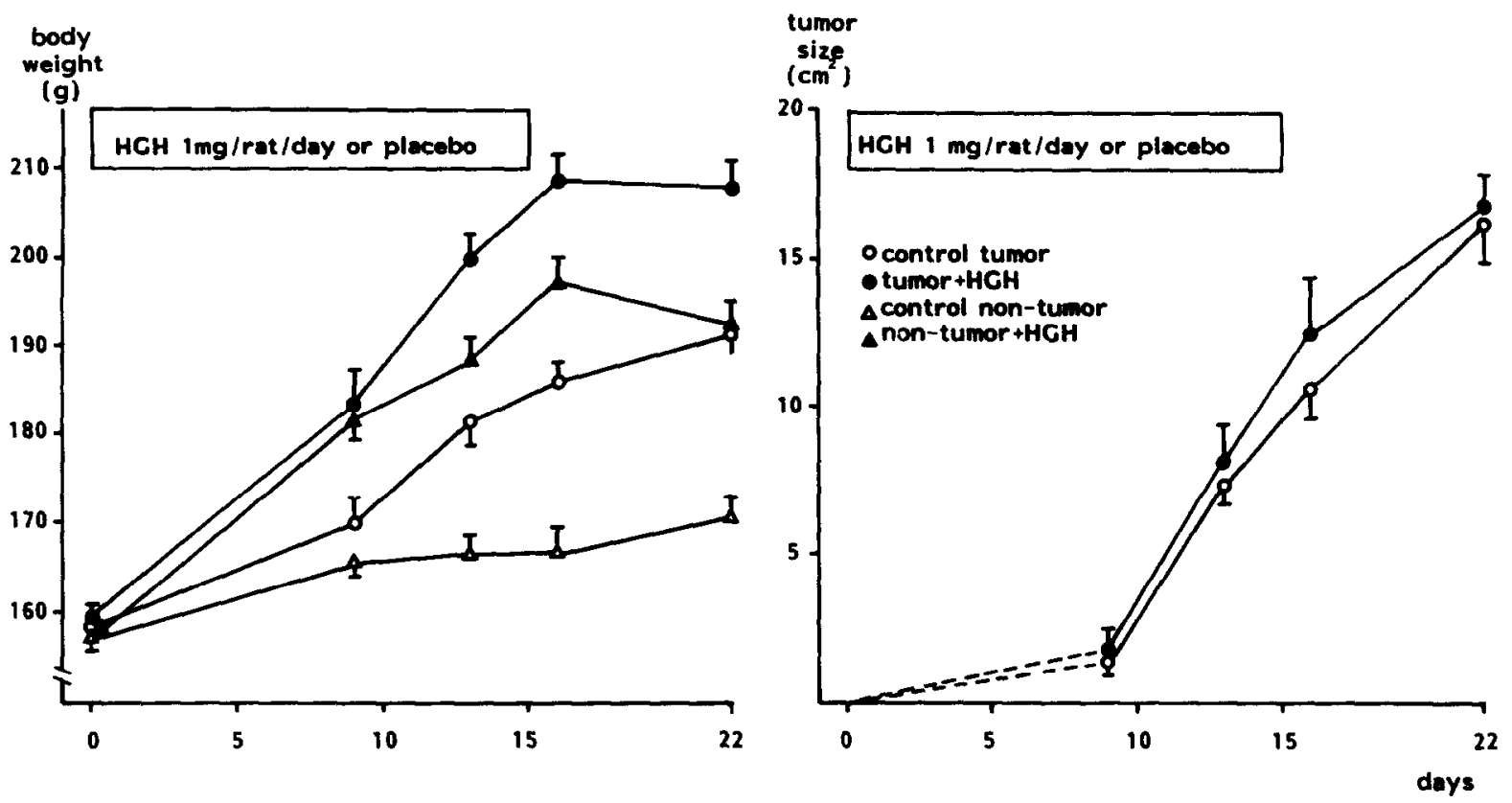

Fig. 3. The effects on body weight, uncorrected for tumor weight (left panel; $\mathrm{g}$ ) and tumor size (right panel; $\left.\mathrm{cm}^{2}\right)$ of the administration of human $G H(1 \mathrm{mg} /$ rat'day) or placebo for 15 days to rats with or without the transplantable rat pituitary tumor $7315 b$ implanted on day $1 . \mathrm{n}=6$ for each group; mean \pm S.E.M. On day 22 body weights corrected for tumor weight were $166 \pm 5$ in the control tumor and $178 \pm 5$ in the HGH treated tumor group.

IGF-I levels, which were significantly higher than in the placebo-treated tumor-bearing animals $(P<0.05)$. These levels were, both on day 9 and 16 , similar to those observed in $\mathrm{GH}$ treated nontumor-bearing rats, and on day 16 also higher than in placebo treated non-tumor-bearing controls $(P<0.05)$. On day 22 the stimulatory effects of GH administration in the first 15 day period had ceased and IGF-I levels had indeed decreased to levels comparable with those in the placebo-treated 
tumor-bearing group. PRL levels in the GH-treated tumor-bearing group again did not differ signifcantly from the placebo-treated tumor-bearing rats $(618 \pm 195$ vs $520 \pm 103 \mathrm{ng} / \mathrm{ml})$. PRL levels were elevated in both tumor-bearing groups compared with both non-tumor-bearing groups (PRL level $35 \pm 6$ in the non-tumor placebo-treated and $26 \pm 7 \mathrm{ng} / \mathrm{ml}$ in the non-tumor GH-treated rats).

\section{DISCUSSION}

Evidence is accumulating that IGF-I plays a role in tumorigenesis and tumor growth. In vitro investigation of several tumor cell lines demonstrate specific binding sites for IGF-I [23-31], increased binding to IGF-I receptors when compared with less dedifferentiated cell lines or with normal surrounding tissue [24, 29-31], production of IGF-I by tumor cell lines or tissue [32,33] and increased DNA synthesis and cell growth in response to IGFI $[23,25,27-29,32,34-36]$.

From these observations one might derive strong arguments against the therapeutic use of GH to reduce catabolism and/or induce an anabolic state in patients with cancer-induced cachexia, since it might simultaneously stimulate grow th of the cancer itself. In addition cvidence was also presented from studies by Friesen's group that GH directly induces the expression of the c-myc oncogene in rat liver [37].

Preliminary results (J. Foekens, personal communication) from investigations into the presence of IGF-I binding sites on the rat pituitary tumor cell line $7315 \mathrm{~b}$ used in this study indicate indeed the presence of specific high affinity IGF-I binding sites on this tumor.

The results of the in vitro studies are in accordance with similar studies in other cancer cell lines, in that it was shown that IGF-I induced cell proliferation and protein (in this case PRL) secretion. GH itself did not induce either effect.

The results of the in vivo studies show that $\mathrm{GH}$ administration for 10-15 days prevents tumorinduced cachexia without stimulating tumor growth measured in $\mathrm{cm}^{2}$ or PRL secretion. On a weight basis we used 120-240 times the GH dosage used in human studies to induce an anabolic state [38].

The discrepancy between the (mitogenic) effect of IGF-I in vitro and the absence of effects of elevated IGF-I levels on tumor growth in vivo might be explained by the possibility with the low IGF-I levels in cachectic animals are sufficient to optimize tumor growth, since the lowest IGF-I level measured in vivo is $14 \mathrm{nM}$, while levels of 10 and $50 \mathrm{nM}$ in the in vilro experiments stimulated cell proliferation to a similar extent. An auto- or paracrine effect of IGF-I generated by the tumor cells themselves cannot be excluded but seems unlikely since we found virtually no IGF-I production by these cells in vitro IGF-I (concentration in the control culture medium after 6 days $0.2 \mathrm{nM}$ ).

Our results are in disagreement with the results of Svaninger et al. [39], who demonstrated no improvement of body composition and muscle wasting (nor an increase in tumor growth) by GH administration in adult, non-growing, sarcomabearing mice, while in hypophysectomized rats GH administration stimulated body and tumor growth to a similar extent. In their sarcoma tumor model in intact animals GH levels were elevated from day 8 after tumor implantation, explained by the authors as a way to promote endogeneous substrate mobilization. The exogeneous $\mathrm{GH}$ dosage was only $100 \mu \mathrm{g} / \mathrm{l} 00 \mathrm{~g}$ body weight day (as opposed to our $\mathrm{GH}$ dose of $1 \mathrm{mg} / \mathrm{rat}$, which corresponds to $600 \mu \mathrm{g} /$ $100 \mathrm{~g}$ body weight/day) which was insufficient to stimulate growth in freely fed control mice. In their study no IGF-I levels were reported.

In our study the decrease of IGF-I levels in tumorbearing rats reflects the tumor induced cachexia [40. 41] and was reversible by GH administration. IGF-I levels decreased to the low level observed in untreated tumor-bearing rats within days after cessation of GH administration.

In conclusion, tumor-induced cachexia in this rat model can be prevented by exogenous GH administration without an increase in tumor mass, even though this tumor model contains specific binding sites for IGF-I and the cultured tumor cells respond to exposure to IGF-I with a mitotic response.

\section{REFERENCES}

1. Van Wijk JJ. The somatomedins: biological actions and physiological control mechanism. Hormonal Proteins Peptides 1984, 12, 81-125.

2. Ward HC, Halliday D, Sim AJW. Protein and energy metabolism with biosynthetic human growth hormone after gastrointestinal surgery. Ann Surg 1987, 206, 56-61.

3. $\mathrm{McK}$ Manson J, Wilmore DW. Positive nitrogen balance with human growth hormone and hypocaloric intravenous feeding. Surgery 1986, 100, 188-196.

4. Ziegler TR, Young LS, McK Manson J, Wilmore DW. Metabolic effects of recombinant human growth hormone in patients receiving parenteral nutrition. Ann Surg 1988, 208, $6-16$.

5. Ponting GA, Halliday D, Teale JD, Sim AJW. Postoperative positive nitrogen balance with intravenous hyponutrition and growth hormone. Lancet 1988, i, 438-439.

6. Torosian MH, Mullen JL, Miller EE, Zinnser KR, Buzby GP. Reduction of methotrexate toxicity with improved nutritional status in tumor bearing animals. Cancer 1988, 61, $1731-1735$ 
7. Nixon DW, Lawson DH, Kutner $\mathrm{M}$ et al. Hyperalimentation of the cancer patient with protein calorie undernutrition. Cancer Res 1981, 41, 2038-2045.

8. Koretz RL. What supports nutritional support? Digest Dis Sci 1984, 29, 577-588.

9. Brennan MF. Total parenteral nutrition in the cancer patient. $N$ Engl J Med 1981, 305, 375-382.

10. Copeland EM, MacFadyen BV, Lanzotti VJ, Dudrick SJ. Intravenous hyperalimentation as an adjunct to cancer chemotherapy. Am J Surg 1975, 129, 167-173.

11. Underwood LE. Report on the conference on uses and possible abuses of biosynthetic human growth hormone. $N$ Engl J Med 1984, 311, 606-608.

12. Watanabe S, Tsunematsu Y, Fujimoto J, Komiyama A. Leukaemia in patients treated with growth hormone. Lancet $1988, \mathbf{i}, 1159$.

13. Fisher DA, Job JC, Preece M, Underwood LE. Leukaemia in patients treated with growth hormone. Lancet 1988, i, 1160.

14. Klein I, Parveen G, Gavaler JS, Vanthiel DH. Colonic polyps in patients with acromegaly Ann Intern Med 1982, 97, 27-30.

15. Ituarte EA, Petrini J, Hershman JM. Acromegaly and colon cancer. Ann Intern Med 1984, 101, $627-628$.

16. Alexander L, $\Lambda$ ppleton D, Hall R, Ross WM, Wilkinson R. Epidemiology of acromegaly in the Newcastle region. Clin Endocrinol 1980, 12, 71-79.

17. Bengtsson BA, Eden S, Ernest I, Oden A, Sjogren B. Epidemiology and long-term survival in acromegaly. Acta Med Scand 1988, 223, 327-335.

18. Nabarro JDN. Acromegaly. Clin Endocrinol 1987, 26, 481-512.

19. Mustacchi $\mathbf{P}$, Shimkin MB. Occurence of cancer in acromegaly and hypopituitarism. Cancer 1957, 10, 100-104.

20. Lamberts SWJ, Uitterlinden P, Verleun T. Comparison of the actions of RU 38486 and megestrol acetate in the model of a transplantable adrenocorticotropin and prolactin secreting rat pituitary tumor. Cancer Res 1985, 45, 1015-1019.

21. Downs TR, Wilfiger WW. Fluoremetric quantification of DNA in cells and tissue. Anal Biochem 1983, 131, 538-547.

22. Lamberts SWJ, MacLeod RM. The inability of bromocriptine to inhibit prolactin secretion by transplantable rat pituitary tumors: observations on the mechanism and dynamics of the autofeedback regulation of prolactin secretion. Endocrinology 1979, 104, 65-70.

23. Furlanetto RW, DiCarlo JN. Somatomedin-C receptors and growth effects in human breast cells maintained in long-term tissue culture. Cancer Res 1984, 44, 2122-2128.

24. Pekonen F, Partanen S, Makinen T, Rutanen E-M. Receptors for epidermal growth factor and insulin-like growth factor I and their relation to steroid receptors in human breast cancer. Cancer Res 1988, 48, 1343-1347.

25. Myal Y, Shiu RPC, Bhaumick B, Bala M. Receptor binding and growth-promoting activity of insulin-like growth factors in human breast cancer cells (' $1-47 \mathrm{D})$ in culture. Cancer Res 1984, 44, 5486-5490.

26. Pollak MN, Perdue F, Margolese RG, Baer K, Richard M. Presence of somatomedin receptors on primary breast and colon carcinomas. Cancer Lett 1987, 38, 223-230.

27. Ritvos O, Rutanen E-M, Pekonen F, Jalkanen J, Suikkari A-M, Ranta T. Characterization of functional type I insulin-like growth factor receptors from human choriocarcinoma cells. Endocrinology 1988, 122, 395-401.

28. Vetter U, Schlickenrieder JHM, Zaph J et al. Human leukemic cells: receptor binding and biological effects of insulin and insulin-like growth factors. Leukemia Res 1986, 10, 1201-1207.

29. Hizuka N, Sukegawa I, Takano K et al. Characterization of insulin-like growth factor I receptors on human erytroleukemia cell line (K-562 cells). Endocrinol Japn 1987, 34, 81-88.

30. Gansler T, Allen KD, Burant CF et al. Detection of type I insulin-like growth factor (IGF) receptors in Wilms' tumors. Am J Pathol 1988, 130, 431-435.

31. Sukegawa I, Hizuka N, Takano K, Asakawa K, Shizume K. Decrease in IGF-I binding sites on human promyelocytic leukemia cell line (HL-60) with differentiation. Endocrinol Japn 1987, 34, 365-372.

32. Huff K, Kaufman D, Gabbay KH, Spencer EM, Lippman ME, Dickson RB. Secretion of an insulin-like growth factor-I-related protein by human breast cancer cells. Cancer Res $1986,46,4613-4619$.

33. Minuto F, Del Monte P, Barreca A et al. Evidence for an increased somatomedin-C/insulinlike growth factor I content in primary human lung tumors. Cancer Res 1986, 46, 985-988.

34. Macauly VM, Teale JD, Everard MJ, Joshi P, Smith IE, Millar JL. Somatomedin-C/ insulin-like growth factor-I is a mitogen for human small cell lung cancer. $\mathrm{Br} J$ Cancer 1988, 57, 91-93.

35. Lippman ME, Dickson RB, Kasid A et al. Autocrine and paracrine growth regulation of human breast cancer. J Steroid Biochem 1986, 24, 147-154.

36. Pavelic K, Vrbanec D, Marusic S, Levanat S, Cabrijan T. Autocrine tumour growth regulation by somatomedin C: an in vitro model. J Endocrinol 1986, 109, 233-238.

37. Murphy LJ, Bell GI, Friesen HG. Growth hormone stimulates sequential induction of cmyc and insulin like growth factor I expression in vivo. Endocrinology 1987, 120, 1806-1812.

38. Binnerts $\Lambda$, Wilson JHP, Lamberts SWJ. The effects of human growth hormone adminis- 
tration in elderly adults with recent weight loss. J Clin Endocrinol Metab 1988, 67, 1312-1316.

39. Svaninger $G$, Isaksson $O$, Lundholm $K$. Growth hormone and experimental cancer cachexia. JNCI 1987, 79, 1359-1365.

40. Clemmons DR, Underwood LE, Dickerson RN et al. Use of plasma somatomedin-C/insulin like growth factor I measurements to monitor the response to nutritional repletion in malnourished patients. Am J Clin Nutr 1985, 41, 191-198.

41. Untcrman TG, Vazquez RM, Slas $\Lambda J$, Martyn P $\Lambda$, Phillips LS. Nutrition and somatomcdin, XIII. Usefulness of somatomedin-C in nutritional assessment. Am J Med 1985, 78, $228-234$. 